AL IBTIDA: JURNAL PENDIDIKAN GURU MI (2019) Vol 6 (2): 204-218

DOI: http://dx.doi.org/ 10.24235/al.ibtida.snj.v6i2.3746

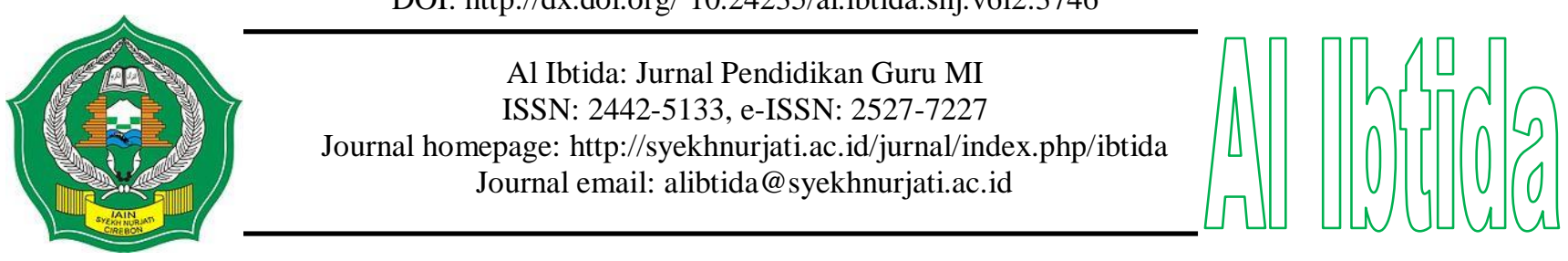

\title{
Teachers' Control System on Negative Impact of Smartphone at Madrasah Ibtidaiyah
}

\author{
Suriana* \\ *Department of Madrasah Ibtidaiyah Teacher Education, Faculty of Tarbiyah and Teacher Training, \\ Institut Agama Islam Negeri Lhokseumawe \\ Email:suryanaff.aceh@gmail.com
}

Received: January $07^{\text {th }}, 2019$. Accepted: September $26 t^{\mathrm{h}}, 2019$. Published: October $29^{\text {th }}, 2019$.

\begin{abstract}
The proliferation of smartphone which are cheap and easy to obtain raises a trend among parents to give their children a smartphone. This situation raises the concern about psychological health and student religiosity. The teachers become the only one who can filter the students and equip them with Islamic values. Thus, they are not swallowed up by the swift flow of digital negatives that are not yet fully understood by students. This research tries to analyze the teachers' control system in limiting the usage of smartphone and providing a negative and positive understanding on the impacts of smartphones at State Islamic Elementary School (MIN) Darul Imarah of Aceh Besar District. This research uses descriptive qualitative methods. The data colection techniques were observation and interview using triangulation for data validity and realibility. The results show that teachers at MIN Darul Imarah district of Aceh Besar, control the use of the negative impact of smartphone on their students by means of; limiting smartphone usage by prohibiting students from taking cellphones to shcool and giving punishmet to those who violate these rules. Furthermore, in providing understanding to students, the teachers do explaining the negative and positive impacts of smartphones in both inside and outside the learning instruction; teaching how to use smartphones smartly; using religious approaches; linking subject matter to the negative impact of smartphones; and socializing the negative impact of smartphones.
\end{abstract}

Keywords: controlling, smartphones, student of Madrasah Ibtidaiyah.

\begin{abstract}
Abstrak
Menjamurnya smartphone yang murah dan mudah diperoleh menimbulkan tren di kalangan orang tua untuk memberikan smartphone kepada anaknya. Keadaan ini menimbulkan kekhawatiran terhadap kesehatan psikis dan religiusitas siswa. Guru menjadi satu-satunya harapan untuk dapat memfilter dan membekali siswa dengan nilai-nilai Islam. Hal ini diperlukan untuk meminimalisir derasnya arus negatif digital yang belum sepenuhnya dipahami oleh siswa. Penelitian ini berusaha menganalisis sistem kontrol guru dalam membatasi pemakaian dan memberikan pemahaman akan dampak negatif dan positif smartphone pada siswa Madrasah Ibtidaiyah Negeri (MIN) di Kecamatan Darul Imarah Kabupaten Aceh Besar. Penelitian ini menggunakan metode kualitatif deskriptif. Teknik pengumpulan
\end{abstract}


datanya adalah observasi dan wawancara dengan menggunakan triangulasi data dalam memvalidasi data. Hasilnya menunjukkan bahwa guru MIN se-kecamatan Darul Imarah Aceh Besar dalam mengontrol pemakaian dampak negatif teknologi komunikasi pada siswanya dengan cara melarang siswa membawa handphone ke madrasah dan memberikan punishmet apabila aturan tersebut dilanggar. Selanjutnya, dalam memberikan pemahaman kepada siswa, guru melakukan dengan cara menjelaskan dampak negatif dan positif smartphone baik di dalam maupun di luar pembelajaran, mengajarkan cara menggunakan smartphone secara cerdas, menggunakan pendekatan religius, mengaitkan materi pelajaran dengan dampak negatif smartphone, mensosialisasikan dampak negatif smartphone kepada orang tua siswa, serta mengadakan program pengembangan kreatifitas siswa.

Kata kunci: pengawasan, smartphone, siswa madrasah ibtidaiyah.

\section{INTRODUCTION}

The development of religious awareness in the current generation of Muslims is increasingly far from the Islamic routine; this is indicated by the busyness of Islamic children with a variety of highly sophisticated communication technology products that continue to develop like mushrooms in the rainy season. This course will undermine the concentration of their learning that they should be wrestling with seriously. The increasingly high level of smartphone usage is due to the rapid development of information technology and is supported by relatively cheap smartphone prices, so that smartphones can be easily and quickly obtained. In addition, the age factor of children who have an interest in always trying and knowing something new is also a factor in the increased use of smartphones among children.

Based on the results of a survey conducted by the Pew Research Center with respondents totaling 30,133 people in 27 countries that have been conducted on May 14 through August 12, 2018, it shows that the comparison of ownership of smartphones and ordinary cell phones among adults shows that Indonesia's position is ranked 24th from 27 countries. Of all adults who have mobile phones in Indonesia, 42 percent have a smartphone, 28 percent have a regular telephone, and 29 percent do not have a mobile phone (Alfarizi, 2019).

The results of this survey are also supported by other data which states that Indonesia is currently a sleeping digital technology giant in Asia. This is because the population of Indonesia currently reaches 260 million people, so that Indonesia is a very large market in the digital world. Indonesian smartphone users will certainly experience rapid growth. Digital marketing research institute Emarketer said in 2018 the number of active smartphone users in Indonesia was more than 100 million people. With such a large number, Indonesia is feared to be the country with the fourth largest active smartphone user in the world after China, India, and America (Rahmayani, 2015). 
Nowadays, smartphone usage does not only come from the workers. However, almost all people, including children and toddlers, are already using smartphones in their daily activities. Almost everyone who uses a smartphone spends a lot of their time a day using a smartphone. Therefore, smartphones also have their own values and benefits for certain people. However, many negative impacts arise in the use of smartphones for teenagers, children, and even toddlers. Although most of the people use smartphones for communication, work or business matters, looking for information, or just for entertainment (Chusna, 2017).

This means that with the condition of most Indonesian parents owning a smartphone, what is most worrying is the children. This is because children use their parents' smartphones given to them to access the virtual world and play games, both offline and online games. This reality opens the curtain of awareness that global phenomena can not be avoided, because it is colonial with a new face that penetrates into various aspects of human life, especially the world of education. The values of Islamic education in general and specifically Islamic education (even traditional pesantren) are now increasingly dissolved in the tumult of various changes in the results of globalization (Suriana, 2014). This communication technology revolution has brought tremendous changes in the order of life of children today. This change is marked by the strong flow of information and communication technology that is almost impossible to hold back by anything and anyone.

The use of smartphones in children of learning age is triggered by the attitude of parents who seem to create this situation. Parents feel worried/ not modern if they do not equip their children with smartphones. After this situation is born, then the parents begin to worry because they lose control of what the child sees, watches or plays through the smartphone that is used. Based on the survey results, one in four children under the age of 6 already has a smartphone. Although parents insist that 11 years is the ideal age for children to have a telephone, the poll found that 25 percent of children aged 6 and under already have their own cellphones. In fact, almost half of the children who have a smartphone spend up to 21 hours per week to play with the device (Supriyadi, 2018).

Parents certainly know that the smartphone has a bad impact on children. If used for a long period of time, these technological devices not only make children addicted, but will also worsen eye health and the child becomes passive, because the child does not get along with his friends and does not do other motor games. In addition to the time spent by children with their smartphones, there are other aspects that are no less important as the adverse effects that children receive from their smartphones. This is the content that is opened by children when playing with a smartphone. The worrying content that children will open is a site that is not good for children aged 6-12 years. If the content opened by children is pornography, this will be more dangerous 
than narcotics. Children can not escape from addiction to pornography that can harm themselves, their families, and even friends around them, because of the event of trial and error of the scenes that he witnessed.

However, even though parents know that giving a smartphone to a child is having a negative impact, but still letting their child use it. This can be triggered due to educational reasons, the introduction of technology from an early age, children like to whine, so that children do not neglect their parents' work, and so on. However, under any pretext, it is still unwise to give freedom to children consuming smartphones, without supervision.

Therefore, the different reasons among parents to give smartphones to their children become homework for teachers in schools to provide control over smartphone use in children of learning age. Teachers are required to be able to provide understanding to children about the positive negative effects of smartphones. This is to avoid the use of smartphones that are not conducive to children, in addition to allowing children to know what they are doing as well as the adverse effects on themselves. Learning by understanding will certainly produce results faster than, forbidden by "violence" without logical understanding reasons, which can be accepted by children. This is a tough task for teachers at school, because not all families have the same perception as teachers, this is the main obstacle for teachers in controlling smartphone usage in elementary school age children.

This difficult task must be borne by the teacher whatever the obstacle, considering that the madrasah ibtidaiyah children are the deciding generations of the future of Islam, even the future of the world. For this reason, teachers are required to immediately take a strategic position in this digital arena. This is because to improve this situation, there is no one more reliable than parents and teachers. It is fitting that these two educators work together to control smartphone usage in the nation's future generation of children.

Therefore, controlling the negative impact of smartphones on madrasah ibtidaiyah children is very important to be done so that they are protected from all the negative effects of communication technology. The inculcation of Islamic values, especially the strengthening of aqidah and noble morals becomes an inevitable reference, so that children are expected to be able to survive with their Islam. Teachers in schools are responsible for directing and controlling and finding accurate steps to regain concentration and religious awareness of these children who are in a troubled time in consuming communication media that continues to roll. Based on the explanation above, this research is important to be carried out with the aim of analyzing the teacher control system in limiting and providing an understanding of the negative and positive effects of smartphone usage on Madrasah Ibtidaiyah Negeri (MIN) students. 
This study is certainly not the first, but there are some previous studies that have become the author's reference to examine the teacher control system in limiting and providing an understanding of the negative and positive impacts of smartphone usage on MIN students. From the searches that have been done, the authors found several studies that are relevant and at the same time become a reference. Among these are studies conducted by Gowthamip \& Venkatakrishnakumarp (2016) which state that there are various impacts of smartphones on society, both positive and negative, both in terms of mobile applications, social impacts, addictions, and even health. To understand the positive and negative impacts of smartphones, it is very important to educate users about how to use smartphones smartly. Education must emphasize increasing positive impacts and highlighting negative impacts clearly so that users can make good use of this information and communication technology. Smartphones can certainly broaden our horizons if we understand the responsibility of using these devices intelligently to get more benefits in business, education, health, and social life. For this reason, it is important to concentrate on how to stop and avoid misuse of smartphones smartly rather than trying to stop or avoid using smartphones.

Furthermore, research conducted by Hardell (2018) about the impact of mobile phones on children and adolescent health. He discovered that brain development is very sensitive to poisons. The greater the absorption of cell phone radiation energy over a long period of time, the greater the sensitivity of the brain, and a long life with the risk of developing brain tumors or other health effects puts children at higher risk than adults. The use of mobile phones in children in the nearest future will cause memory disturbances, decreased attention, reduced learning and cognitive abilities, increased irritability, sleep problems, increased sensitivity to stress, and increased epileptic readiness. Estimated long-term health risks include brain tumors, acoustic and vestibular nerve tumors (aged 25-30 years), Alzheimer's disease, dementia, depressive syndrome, and other types of degeneration of the brain's nerve structure (aged 50-60).

Similar research has also been carried out by Pathak, Kadali, \& Saraiya (2018) who study the "Comprehensive Study on Negative Effects of Mobile Phones / Smart Phones on Human Health". He explained that there are several negative impacts on smartphones for health. First is about eye health, sudden changes in graphics, brightness and detail when playing games are one of the main causes of chronic dry eye syndrome. Second, stress when not using a smartphone. Addiction to smartphones is now referred to as Nomophobia (no-mobile-phonephobia). Survey results show that $84 \%$ of the world's population says that they cannot walk once a day without their smartphone, and current research shows that nearly two-thirds of teens and young adults check their cellphones every 15 minutes or less. Third is about lifestyle diseases. It is a common sight for teenagers and even tired adults to spend hours on smartphones, be it gaming or surfing 
the internet. This affects digestion, breathing speed, and heart rate. Fourth is about problem with the body. Staring at a cellphone for a long time with a bent neck and arms in a fixed position poses serious health risks such as pain, muscle spasms, and restlessness are only short-term effects. In the long run permanent or chronic diseases can occur such as; cervical spondylitis, golfer's elbow, chronic dry eye syndrome, and thumb stiffness. Last is shaking the focus.

The above research is focused on the medical effects caused by the use of smartphones in children. So great is the danger of smartphone radiation for brain development and health for children, because it will outlive adult users. This problem is a critical challenge for millions of young users and needs to be effectively studied further. Even need to be well studied such as the behavior of sending messages, daily use, mobile disruption, sleep disturbance, sexual relations, impaired driving, and the effects of radiation. For this reason, more innovative research efforts are needed to better understand the behavior of these phones. For this reason, this research is one of these innovative efforts to understand the negative and positive impacts of smartphones on the character of children, especially madrasah ibtidaiyah children. His findings are expected to be a constructive input for educators to avoid the negative effects of smartphones and develop the positive side as a learning medium.

Furthermore, Karman (2012) in his study examined the use of digital media among children and adolescents. His research aims to get information and entertainment including social media, where one of the places they access the internet is internet cafe. According to the results of his research, most internet cafes are not equipped with filtering technology or notice in the form of pamphlets or other, and there are still many cafes that have never received a healthy internet socialization. So that the negative side of the use of the internet is more dominant than the positive side, the negative impact found is the use of the internet as a medium for dating and also an avid child playing online games and encouraging children and adolescents to commit juvenile delinquency (stealing money, harassing, and using time disproportionately). While the positive side is the internet helps with school work. Therefore, the government is expected to deal with the negative impacts of internet use. This study only looked at the negative and positive effects, but did not see the control that was done by the teacher in filtering the negative impacts and developing the positive side.

Furthermore, the research results of Fitriyadi (2013) on the integration of communication information technology in education show that there are several potential benefits of ICT for education, namely: (1) functioning as an enabler for lifelong learning; bring about changes in the teacher's role in teaching and the role of students in learning; providing open access to interactive material and information through networks; eliminate time and space constraints in the learning environment; and open opportunities for collaboration between teachers and 
between students, 2) to create a knowledge-based society, 3) the process of internalizing values in ICT learning can be transformed with culture in the school environment by integrating value education in teaching materials so that habituation, assignment, and modeling become an integral, holistic part, which is continuously being studied, understood, practiced in daily life, and 4) Implementation strategies and professional development in the field of ICT must refer to learning and teaching activities.

The above research becomes a reference and reference that technology is not an enemy, but a friend who can turn into a dangerous enemy if not treated intelligently. For this reason, this study aims to analyze teacher control systems in limiting smartphone use and provide an understanding of the negative and positive impacts of smartphones on madrasah ibtidaiyah students.

\section{METHODS}

This research is a qualitative study, a research that intends to understand the phenomena about what is experienced by research subjects (Moleong, 2008). Information or data of this research is in the form of an understanding of the meaning, whether it is obtained from data in the form of oral, interaction with respondents, or in the form of writing obtained through data and other official records. Steps taken to find opportunities based on existing assumptions and theories make it possible to bring up the teacher control system on the negative impacts of information and communication technology in MIN throughout the Darul Imarah Aceh Besar District.

This type of research is a qualitative descriptive analysis, which seeks to describe each event and its relation to the people involved in a particular situation. This study seeks to examine each conceptual side of the subject under study in such a way that it understands what and how an understanding develops around research within the scope of the object's life. The steps taken are to provide a description of qualitative analysis by forming abstractions by interpreting data based on the object's point of view (Moleong, 2008).

As for the location of this research is madrasas ibtidaiyah in the Darul Imarah sub-district of Aceh Besar District. Taking the location of research in this district because of the observations of researchers there is a phenomenon as described in the background of the problem so that it is more accurate in obtaining data. In this study, the sources of the data are derived from all the results of interviews with teachers in controlling the negative impact of smartphones on students of madrasah ibtidaiyah and student behavior. The research instrument that researchers used in this study was observation of the behavior of madrasa students where researchers conducted research. Next is interviews with teachers who teach in high school madrasa ibtidaiyah in the Darul Imarah sub-district of Aceh Besar District. Furthermore, researchers also conducted a documentation study to obtain data in the form of information or information needed related to 
research, namely the teacher control system of madrasah students related to the negative impact of the use of information and communication technology, both written and academic and administrative data.

This data is then analyzed using triangulation techniques using four modes performed, namely data sources, methods, investigators / investigators, and theories (Asrori, 2014). This mode means that information obtained from one data source is validated in context with other data sources. The technique was obtained through (1) comparing observational data with interview results; (2) comparing information conveyed by someone in public with what is said in private; (3) comparing the information referred to with the research situation with what was said all the time; (4) comparing the circumstances and perspectives of someone arguing as an ordinary citizen, with educated and government officials; (5) comparing the results of interviews with the contents of a related document (Moleong, 2008).

Triangulation of data sources also provides an opportunity to do (1) assessment of research results conducted by respondents, (2) correct errors by data sources, (3) provide additional information in voluntary, (4) include informants in the research arena, create opportunities to summarize as an initial step in data analysis, (5) assesses the overall adequacy of the data collected (Bugin, 2007).

\section{RESULTS AND DISCUSSION}

\section{Teacher Control Systems in Limiting Smartphone Use}

Starting data collection on how the teacher controls the limits of smartphone usage in these madrasah ibtidaiyah children, the researchers delved in advance about the teacher's understanding of the characteristics of madrasah ibtidaiyah age children and smartphones. This is to draw a straight line between the control done by the teacher to the child with his understanding of the characteristics of the age of madrasah ibtidaiyah children and the functions, benefits, and disadvantages of using this smartphone. In Darul Imarah sub-district there are 4 Madrasah Ibtidaiyah Negeri (MIN), namely MIN Punie, MIN Jeumpet, MIN Cot Gue, and MIN Keutapang.

Based on the results of interviews with these teachers it was found that the majority of teachers already understood the development of children aged class IV to class VI well. This can be seen from the statement of the MIN teachers in the Darul Imarah sub-district of Aceh Besar District that the MIN high-class students are at the age of learning, their curiosity is extraordinary, so the teacher always tries to provide a positive understanding, and a good example related to what all they want to know, including regarding the use of smartphones. In addition, the teacher also provides good examples for students, so that they imitate good behavior as well. This explanation is synergized with Yusuf (2004) which states that the stage of 
development of social behavior in children aged MI is characterized by the expansion of relationships in addition to the family also begins to form new bonds with peers (peer groups), so that the space for social relationships is expanding. At this age children begin to have the ability to adjust themselves (egocentric) to the attitude of cooperation (cooperative) or sociocentric.

The development of operations of letting the children free from the need of smartphone deal directly with the environment because in this case, the child is able to carry out symbolic manipulation. The development of operations (interiored action) gives the child a complex way to handle the environment, and therefore, the child is able to carry out more complex intellectual actions. Since the cognitive structure of children is more articulated, Likewise the physical environment of children, so it can be said that the cognitive structure of children constructs the physical environment (Ibda, 2015). The construction of brain tissue will only live if programmed through stimulation. Without being stimulated or used, the human brain will not develop. Because brain growth has limited time, brain stimulation at an early age is very important. The delay that occurs keeps the brain closed so that it cannot accept new programs (Murti, 2018).

Then, the teachers at MIN understand the developmental conditions of Madrasah ibitidaiyah children, especially in the class they teach. This will certainly have a good impact on the learning methods they apply. Based on the results of interviews and observations conducted by researchers, found a number of ways taken by teachers in limiting the use of smartphones in children aged Madrasah Ibtidaiyah. Efforts made by the teacher include a) prohibiting students from bringing communication tools to madrasas; and b) giving punishmet to students who violate the rules prohibiting bringing smartphones to madrasas. However, the madrasa gives concessions to the application of this rule, for several reasons. If students are ill and parents have an important need to contact their children when the child is at school.

If there are students who violate this rule they will be given sanctions in accordance with the level of violations committed. This sanction is carried out in several stages, namely a) giving advice with the aim of guiding students not to violate again; b) confiscated a smartphone. If the advice given by the teacher is not obeyed by the students, then the teacher will confiscate the smartphone that the student brings to the madrasa. This is a follow-up to the first phase of sanctions; c) call parents of students to school. If violations committed by students can no longer be handled by the madrasa, the madrasa head will call the parents of students to madrasa for coaching and joint commitment to comply with this prohibition. Regarding the sanctions imposed in this madrasa, it appears that the stages start from the mildest first and then the middle level up to the most severe namely calling parents to the madrasa for guidance. School rules, teacher authority, work discipline, ways of learning, sociability, and various strict school demands will provide aspects of beauty and enjoyment in learning for children aged 6-12 years 
(Kartono, 1995). However, of course the application of this rule is done wisely, politely, and disciplined, so that the madrasas feel the benefits together.

The development of internet users in Indonesia is very rapid. In the past five years the number of internet users has increased by $430 \%$. At the end of 2015, internet users in Indonesia had reached 88.1 million. About $90 \%$ of internet users are from social media users. Based on statistical reports there are around $92 \%$ of social media users aged between 13-39 years. That means there are around 73 million social media users who have the potential to popularize Islamic science content on social media. Islamic science was born from the spirit of Muslim scientists and academics to integrate Islam and science / science. There are some Islamic science content that can be packaged in social media: 1) scientific content in Islam, 2) Muslim inventor content 3) study the contents of the latest findings in Islamic view, 3) content of wise words from Scientists (Irwandani, 2016).

\section{Teacher Control Systems in Providing Understanding of the Negative Impact of Smartphones}

Based on the results of interviews conducted by researchers with teachers in MIN throughout the Darul Imarah sub-district of Aceh Besar District, the teacher routinely provides guidance and guidance both in the face-to-face learning process with students about the negative and positive impacts of smartphones. Teachers at Madrasah have taken several ways in providing an understanding of the negative and positive impacts of using smartphones on their students. The way that teachers do, among others:

a. Explaining the impact of using a smartphone for student

Provide an explanation of the negative and positive impacts of using smartphones for students both in the learning process and outside the learning process, for example when listening to students use cyberspace or discuss the types of accounts they have with their friends.

b. Teaching how to use smartphone wisely.

The teacher guides students to become users of smartphones that are full of filters, for example giving assignments to students to access the internet at home, but must be accompanied by parents in making these assignments.

c. Using religious approach

Using a religious approach is intended to have students become a religious generation and not affected by the dangers of today's smartphones which are very worrying. These negative impacts can be minimized by reinforcing religious foundations, mastering Islamic scholarship, and learning science relevant to the development of science and technology (Muhtarom, 2005). In the global era, Islamic education faces two major challenges, namely 
the moral crisis and the crisis of personality. The factors that cause this challenge are due to the loosening of the grip on religion by prioritizing science, the ineffectiveness of moral guidance carried out by the family by exemplification and habituation. The swift flow of global negative cultural information, include hedonism, secularism, pornography, and others.

To deal with such conditions requires a special strategy to strive for the implementation of Islamic religious education effectively and efficiently. This effort can be done by implementing and internalizing the values of Islamic teachings into the personalities of students which include; riyādah, which can project the intelligence of students (reason/IQ, heart/EQ, and ruhiyah/SQ), Train students to have awareness of tafakur, tazakur, and tadabur. Furthermore, getting used has the nature of mahmūdah (praiseworthy), and avoiding the nature of mazmudah (split), so that it becomes a complete Muslim. Furthermore, Mujāhadah means the seriousness of students against and controlling their desires (Sukring, 2016). The results of this study answer that teachers have a special strategy to embrace the Islamic generation into the embrace of Islam, so that they can fortify themselves from the enormity of the influence of smartphones that erode Islamic values.

d. Connecting the lesson with the bad effect of smartphone.

Link the subject matter being taught by the teacher to the dangers of smartphones and provide examples of tragic events in the community. There are also teachers who spend 5 minutes at the beginning of learning to explain this negative side to students, because they know students have smartphones in their homes. Thus, it appears that teachers do not remain silent in the face of the influence of smartphones, but still try hard so that their students are filtered in this millennial era.

The steps for shaping students' character as learning is understanding the unique learning profile and painting a portrait of what allows each student to be successful, appreciation and desire to better understand a variety of lessons is very important and create a student-centered learning environment. In-depth learning to shape students 'characters as learners is to help students understand themselves as learners to improve students' understanding of their strengths, weaknesses and affinity; building the value of trust among student learning groups; and able to synergize learning with other students. Suggestions for further research can experiment with deep learning in the learning process (Anwar, 2017).

e. Motivating the students to avoid the bad effect of smartphone.

The teacher's role as a motivator is certainly very much needed in the learning process, this is because the madrasa ibtidaiyah students are at the age of learning and are in dire need of extrinsic motivation both from their parents and teachers. It is wise if teachers take this path to convince students not to be influenced by the negative side of today's smartphones. 
The madrasah ibtidaiyah teachers in the Darul Imarah sub-district tried to motivate students not to spend much time on smartphones, but rather to promote traditional games, which built more cohesiveness and functioned throughout the students' psychomotor, and used the time to memorize the Qur'an.

This is because, despite having a large positive impact, especially in the field of education and communication, excessive use of smartphones for children also has several negative impacts. Pediatrician from the United States, Cris Rowan, in writing in the Huffington Post, said there needs to be a ban on the use of smartphones in children under 12 years because it can cause brain growth too fast, sleep disorders, obesity, mental illness, aggressive and digital senile (Palar, Onibala, \& Oroh, 2018). Furthermore, a conducive school climate and culture is characterized by the creation of a safe, comfortable and orderly learning environment so that learning can take place effectively. A conducive school climate and culture are very important so students feel happy and positive towards their school, so that teachers feel valued, parents and the community feel accepted and involved (Zahro, 2015).

f. Giving information about the bad effect of smartphone to the parents.

This socialization was carried out as an effort to minimize the negative impact of the smartphone for students at home. This is because not all smart parents use smartphones, especially those who have lower secondary education. This activity is carried out by the school when taking a student report card or meeting parents / guardians. A positive activity when the madrasa takes care of the situation of students at home, in this case providing understanding to parents of the negative impact of smartphones on students.

g. Student self development program.

The personal development program is a good program developed by the school, so students can develop their talents and hobbies creatively and innovatively. With this activity, it is expected that students become more time-consuming to develop themselves rather than neglect the game or watching videos that are not necessarily right for their age. However, in order to be able to adjust the types of student performance programs, the teacher must first analyze the student's behavior and characteristics, to find students' talents and interests so that they can be realized in extra-curricular activities in the school.

After knowing the philosophy of teaching, teachers should also pay attention to teaching strategies in increasing student creativity. The things that can be done by teachers in developing student creativity, among others: First, provide opportunities for students to choose the topic or what activities they will do in solving a problem. Second, it is necessary to involve students in assessing their work. Third, the teacher gives prizes that are intangible (non material) such as words of appreciation, smiles or nods when students successfully solve 
a problem (Mao, You, Zhang, Huang, \& Letaief, 2017). The same situation is also in sync with research conducted by Asif \& Rahmadi (2017) which states that there is a relationship between the level of smartphone addiction and emotional and behavioral disorders of adolescents aged 11-12 years. For example students are difficult to communicate with, do not care and respond less when parents invite them to talk, and others.

Thus, the description of the research findings above shows that schools forbid students from carrying a smartphone, but that does not mean the school is completely ignorant of the adverse effects of smartphones on their students. That is, the location of the school is on the outskirts of the city, but digital culture is the same as what happens with schools that are in the middle of the city. This is the advantage of smartphones that erase the isolation of villages and cities, everything becomes easy and fast. This makes the teacher unable to turn a blind eye to this worrisome condition. The teacher also explained that sometimes there were guardian parents who used their children's scholarship money to buy smartphones for their children. For this reason, the rules and the stages of control conducted by this teacher, it shows that the teacher's role is very important and the only thing that is accepted by students to filter students in using smartphones. Teachers are required to be able to educate students so that they become wise smartphone users and to facilitate the learning process, not vice versa.

\section{CONCLUSION}

Based on the results of research and discussion, it can be concluded that there are two ways in which teachers control smartphone use in madrasah ibtidaiyah children in madrasah ibtidaiyah in Darul Imarah, Aceh Besar District. First, it prohibits students from bringing smartphones to madrasas. Second is giving punishmet to students who break the rules prohibiting bringing smartphone to Madrasah. Furthermore, if there are students who violate this rule they will be given sanctions in accordance with the level of violations committed. First is giving advice with the aim of guiding students not to violate again. Second is confiscating smartphones. Third, call students' parents to school, if violations committed by students can no longer be handled by the madrasa. In providing an understanding of the negative and positive impacts of using smartphones on students, the teachers conveyed them in the learning process and outside the learning process. The teachers teach how to use smartphones intelligently using a religious approach and linking subject matter with the negative impact of smartphones. The teachers also develop self-development programs for students, so students can develop their talents and interests creatively and innovatively. The results of this study are also expected to be a role model for other Madrasah Ibtidaiyah in order to control smartphone usage in Madrasah Ibtidaiyah. 


\section{REFERENCES}

Alfarizi, M. K. (2019). Tempo.com. Retrieved Agutus 2019, 4, from https://tekno: https://tekno. tempo. $\quad$ co/read/1181645/survei-kepemilikan-smartphone-indonesia-peringkat-ke$24 /$ full\&view $=$ ok

Anwar, M. (2017). Pembelajaran Mendalam untuk Membentuk Karakter Siswa sebagai Pembelajar. Tadris: Jurnal Keguruan Dan Ilmu Tarbiyah, 2(2), 97-104.

Asif, A., \& Rahmadi, F. (2017). Hubungan Tingkat Kecanduan Gadget dengan Gangguan Emosi dan Perilaku Remaja Usia 11-12 Tahun [Relationship between Gadgets Addiction Levels and Teenage Emotions and Behavior Ages 11-12 Years Old]. Jurnal Kedokteran Diponegoro, 6(2), 148-157.

Asrori, M. A. (2014). Metodologi \& Aplikasi Riset Pendidikan. Jakarta: Bumi Aksara.

Bugin, M. B. (2007). Metode Penelitian Kualitatif: Komunikasi Ekonomi dan Kebijakan Public serta Ilmu-ilmu Sosial Lainnya. Jakarta: Kencana.

Chusna, P. A. (2017). Pengaruh Media Gadget pada Perkembangan Anak dan Remaja. Dinamika Penelitian: Media Komunikasi Sosial Keagamaan, 17(2), 316-317.

Fitriyadi, H. (2013). Integrasi Teknologi Informasi Komunikasi Dalam Pendidikan: Potensi Manfaat, Masyarakat Berbasis Pengetahuan, Pendidikan Nilai, Strategi Implementasi Dan Pengembangan Profesional. Pendidikan Teknologi Kejuruan, 21(3), 269-284.

Gowthamip, S., \& Venkatakrishnakumarp, S. (2016). Impact of Smartphone : A Pilot Study on Positive and Negative Effects. International Journal of Scientific Engineering and Applied Science, 3(2), 2395-3470.

Hardell, L. (2018). Effects of Mobile Phones on Children's and Adolescents' Health: A Commentary. Child Development, 89(1), 137-140.

Ibda, F. (2015). Perkembangan Kognitif: Teori Jean Piaget. Jurnal Intelektualita. Jurnal Intelektualita, 3(1), 27-38.

Irwandani, I. (2016). Potensi Media Sosial dalam Mempopulerkan Konten Sains Islam. Tadris: Jurnal Keguruan dan Ilmu Tarbiyah, 1(2), 173-177.

Karman. (2012). Pola Penggunaan Media Digital di Kalangan Anak dan Remaja (Kasus di Kota Jayapura Provinsi Papua). Jurnal Penelitian Pos dan Informatika, 2(1), 35-50.

Kartono, K. (1995). Psikologi Anak: Psikologi Perkembangan. Bandung: Mandar Maju.

Kau, M. A. (2017). Peran Guru dalam Mengembangkan Kreatifitas Anak Sekolah Dasar. Seminar dan Lokakarya Revitalisasi Laboratorium dan Jurnal Ilmiah dalam Implementasi Kurikulum dan Bimbingan Konseling Berbasis KKNI (pp. 157-166). Malang: journal2.um.ac.id.

Mao, Y., You, C., Zhang, J., Huang, K., \& Letaief, K. B. (2017). A survey on mobile edge computing: The communication perspective. IEEE Communications Surveys \& Tutorials, 19(4), 2322-2358.

Moleong, L. J. (2008). Metodologi Penelitian Kualitatif. Bandung: Remaja Rosdakarya.

Muhtarom. (2005). Reproduksi Ulama di Era Global: Resistransi Tradisional Islam. Jakarta: Pustaka Setia.

Murti, T. (2018). Perkembangan Fisik Motorik dan Perseptual Serta Implikasinya pada Pembelajaran di Sekolah Dasar. Wahana Sekolah Dasar, 26(1), 21-28. 
Palar, J., Onibala, F., \& Oroh, W. (2018). Hubungan Peran Keluarga dalam menghindaro dampak Negatif Penggunaan Gadget Pada Anak Dengan Perilaku Anak Dalam Penggunaan Gadget. Jurnal Keperawatan, 6(2), 1-8.

Pathak, D., Kadali, H., \& Saraiya, W. (2018). A Machine Learning Approach to Stock Forecasting. International Journal of Innovative Research in Computer and Communication Engineering, 6(1), 8228-8237.

Rahmayani, I. (2015). Indonesia Raksasa Teknologi Digital Asia. Jakarta: Kementerian Komunikasi dan Informatika Republik Indonesia.

Sukring, S. (2016). Pendidik dalam Pengembangan Kecerdasan Peserta Didik (Analisis Perspektif Pendidikan Islam). Tadris: Jurnal Keguruan dan Ilmu Tarbiyah, 1(1), 57-68.

Supriyadi, E. (2018). Seperempat Anak Di Bawah 6 Tahun Sudah Miliki Smartphone. Jakarta: Republika.co.id.

Suriana. (2014). Pendidikan Islam di Era Globalisasi: Menggapai Peluang Menuai Tantangan. Jurnal MUDARRISUNA: Media Kajian Pendidikan Agama Islam, 4(2), 356-375.

Yusuf, S. (2004). Psikologi Perkembangan Anak dan Remaja. Bandung: Remaja Rosdakarya.

Zahro, L. (2015). Urgensi Pembinan Iklim Dan Budaya Sekolah. Jurnal Pendidikan Agama Islam (Journal of Islamic Education Studies), 3(1), 157-186. 